\title{
Serum p53 Antibody Is Not Associated with p53 Immunoreactivity in Patients with Pancreatobiliary Cancers
}

\author{
Junko Umeda, ${ }^{1}$ Takao Itoi, ${ }^{1}$ Atsushi Sofuni, ${ }^{1}$ Fumihide Itokawa, ${ }^{1}$ Toshio Kurihara, \\ Takayoshi Tsuchiya, ${ }^{1}$ Kentaro Ishii, ${ }^{1}$ Shujiro Tsuji, ${ }^{1}$ Nobuhito Ikeuchi, ${ }^{1}$ Reina Tanaka, ${ }^{1}$ \\ Ryosuke Tonozuka, ${ }^{1}$ Mitsuyoshi Honjo, ${ }^{1}$ Shuntaro Mukai, ${ }^{1}$ Toshitaka Nagao, ${ }^{2}$ \\ Hisashi Oshiro, ${ }^{2}$ and Fuminori Moriyasu ${ }^{1}$
}

${ }^{1}$ Department of Gastroenterology and Hepatology, Tokyo Medical University, Tokyo 160-0023, Japan

${ }^{2}$ Department of Pathology, Tokyo Medical University, Tokyo 160-0023, Japan

Correspondence should be addressed to Junko Umeda; junko.umeda@gmail.com

Received 19 June 2013; Accepted 18 November 2013

Academic Editor: Paul Magnus Schneider

Copyright (C) 2013 Junko Umeda et al. This is an open access article distributed under the Creative Commons Attribution License, which permits unrestricted use, distribution, and reproduction in any medium, provided the original work is properly cited.

\begin{abstract}
Background. Recent diagnostic imaging tests contribute to improving the diagnosis of pancreatobiliary cancers. However, it is not practical to perform these tests for all patients as screening. Thus, less-invasive and simple screening tests are still required. A method to detect the IgG antibody induced in serum against the p53 protein accumulating due to p53 gene mutation, as a biomarker, was developed around 1990. Method. 35 patients with pancreatic cancer, 12 patients with biliary tract cancer, and 31 patients with benign pancreatobiliary diseases were entered into this study. Measurement of serum anti-p53 antibody was conducted in all patients. In addition, the rate of $\mathrm{p} 53$ protein overexpression was examined in those cases that could be examined pathologically. Result. Among all patients in the pancreatic cancer and biliary tract cancer groups, there was no patient with serum anti-p53 antibody positive value that exceeded the standard value. The rate of p53 protein overexpression was $48.0 \%$ in the patients with pancreatobiliary cancers and $0 \%$ in the benign pancreatobiliary diseases group. Conclusion. Serum anti-p53 antibody measurement does not contribute to the diagnosis of pancreatobiliary cancers. Instead, traditional p53 immunostaining still appears to be valuable in combination with standard procedures.
\end{abstract}

\section{Introduction}

Recent diagnostic imaging tests such as computed tomography $(\mathrm{CT})$ and magnetic resonance imaging (MRI) contribute to improving the diagnosis of pancreatobiliary cancers [1-4]. However, from the point of cost benefit, it is not practical to perform these tests for all patients as screening. Thus, lessinvasive and simple screening tests are still required.

As screening tests, hematology tests are known to be the most simple and minimally invasive. CA19-9 and CEA have been reported as comparatively useful tumor markers for pancreatobiliary cancers [5-7]. On the other hand, various forms of gene mutation are now present in the cancer chemotherapy process in pancreatobiliary cancers. Among these genes, mutation of the $\mathrm{p} 53$ gene has been reported in various tumors [8], and even in pancreatobiliary cancers it has been found at the rate of 30 50\% [9-13], and in pancreatic cancer at the rate of $60 \%$ [14]. Infiltrative cancers in particular have been reported to have a high rate of at least $70 \%$ of gene mutation [15]. Apart from the detection of such gene mutation, a method to detect the IgG antibody (serum antip53 antibody) induced in serum against the p53 protein accumulating due to p53 gene mutation, as a biomarker, was developed around 1990 [16]. Shimada et al. reported the usefulness of the measurement of serum anti-p53 antibody in various malignant tumors [16-20] and suggested that it is clinically useful particularly in cancers that are in the early stage comparatively, where the positive rate is high. As a novel tumor marker for esophageal cancer, colon cancer, and breast cancer, it became eligible for health insurance coverage from 2007 in Japan. Moreover, it has been shown to be useful even in the prediction of prognosis during the treatment process of 
TABLE 1: Clinical characteristics of patients with pancreatobiliary cancer.

\begin{tabular}{lcc}
\hline & $\begin{array}{c}\text { Pancreatic cancer } \\
(N=35)\end{array}$ & $\begin{array}{c}\text { Biliary tract cancer } \\
(N=12)\end{array}$ \\
\hline Age (Yr) & 69.3 & 72.3 \\
Median (range) & $(51-83)$ & $(54-88)$ \\
Sex (no.) male/female & $19 / 16$ & $8 / 4$ \\
Stage (no.) & $2 / 0 / 4 / 13 / 16$ & $0 / 1 / 2 / 3 / 6$ \\
(I/II/III/IVa/IVb) & Head 16 & Gallbladder 4 \\
Primary tumor site (no.) & $\begin{array}{c}\text { Body 12 } \\
\text { Tail 7 }\end{array}$ & Bile duct 8 \\
\hline
\end{tabular}

cancers and relapse in postsurgery cases [21]. On other hand, it is expected to be useful in the measurement of serum antip53 antibody as in gastrointestinal cancer even in malignant pancreatobiliary tumors.

In the present study, serum anti-p53 antibody was measured in patients with pancreatobiliary cancer. Serum antip53 antibody measurement was performed for cases of pancreatobiliary cancer experienced at our institution. In addition, the rate of $\mathrm{p} 53$ protein overexpression was examined in those cases that could be examined pathologically.

\section{Materials and Methods}

2.1. Samples. 35 patients with pancreatic cancer, 12 patients with biliary tract cancer (Table 1), and a control group consisting of 31 patients with benign pancreatobiliary diseases (13 with common bile duct stones, 6 with chronic pancreatitis, 4 with benign bile duct stricture, 2 with pancreatic pseudocyst, 2 with autoimmune pancreatitis, 2 with adenomyomatosis of the gallbladder, 1 with pancreatobiliary maljunction, and 1 with benign pancreatic duct stricture) (Table 2) that had been hospitalized for treatment at this institution between December 2010 and April 2011 were entered into this study. Mean age was 69.3 years (range, $51-83$ years) for pancreatic cancer, 72.3 years (range, 55-88 years) for biliary tract cancer, and 65.0 years (range, 35-86 years) for benign pancreatobiliary tract disease. The male-to-female ratio was 19:16 for pancreatic cancer, 8:4 for biliary tract cancer, and 25:6 for benign pancreatobiliary tract disease.

2.2. Serum Level of CA19-9, CEA, and Anti-p53 Antibody. Serum CA19-9, CEA, and anti-p53 antibody were determined for all patients prior to treatment. The required serum sample of $0.3 \mathrm{~mL}$ was used to measure anti-p53 antibody by ELISA and the measurement kit was MESACUP anti-p53 TEST (Medical Biological Research Institute Inc., Tokyo, Japan). A value $\geq 1.30 \mathrm{U} / \mathrm{mL}$ was judged as anti-p53 positive.

2.3. p53 Immunohistochemical Analysis. In addition, immunostaining was performed with p53 protein (D0-7, DAKO, Glostrup, Denmark) by the SAB method on formalin-fixed paraffin-embedded fragments obtained from those patients from whom adequate tissue samples could be obtained by biopsy or surgical resection. Cells with nuclei
TABLE 2: Clinical characteristics of patients with benign disease.

\begin{tabular}{llc}
\hline$N$ & 31 & \\
Age (Yr) & 65.0 & \\
Median (range) & $(35-86)$ & \\
Sex (no.) & $25 / 6$ & 13 \\
male/female & & 6 \\
& CBD stone & 4 \\
& Chronic pancreatitis & 2 \\
& Bile duct stricture & 2 \\
Disease $(n)$ & Autoimmune pancreatitis (AIP) & 1 \\
& Adenomyomatosis (ADM) of the gallbladder & 2 \\
& Pancreatic pseudocyst & 1 \\
\hline & Pancreaticobiliary maljunction & \\
& Pancreatic duct stricture & \\
\end{tabular}

stained brown were judged as positive cells. A comparison was made with $\mathrm{HE}$ staining (Figure 1) and the percentage of cancer cells that were positive was calculated. A rate of $\geq 70 \%$ was judged as overexpression of p53 protein. Moreover, a comparison was made with the staining results of noncancerous epithelium of the same fragment to determine the diagnostic performance of cancer by p53 protein overexpression.

\section{Statistical Analysis}

Diagnostic accuracy, sensitivity, and specificity of each marker were calculated and compared with the final diagnosis. Statistical analysis was performed using chi-square test. A $P$ value less than 0.05 was regarded as indicating a statistically significant difference. Statistical analyses were performed with StatMate III (ATMS Co. Ltd., Tokyo, Japan).

\section{Results}

4.1. Serum Level of CEA and CA19-9. Mean CEA (standard value: $<5.0 \mathrm{ng} / \mathrm{mL}$ ) in the pancreatic cancer group was $38.33 \mathrm{ng} / \mathrm{mL}$, the positive rate was $42.8 \%$, mean CA19-9 (standard value: $<37 \mathrm{U} / \mathrm{L}$ ) was $3142.92 \mathrm{U} / \mathrm{L}$, and the positive rate was $85.7 \%$. In addition, mean CEA in the biliary tract cancer group was $21.42 \mathrm{ng} / \mathrm{mL}$, the positive rate was $41.6 \%$, mean CA19-9 was $5859.88 \mathrm{U} / \mathrm{L}$, and the positive rate was $91.6 \%$. In the pancreatobiliary cancer group, mean CEA was $34.01 \mathrm{ng} / \mathrm{mL}$, the positive rate was $74.0 \%$, mean CA19-9 was $3836.6 \mathrm{U} / \mathrm{L}$, and the positive rate was $87.2 \%$ (Tables $3,4,5$, and 6).

4.2. Serum Level of Anti-p53 Antibody. Among all patients in the pancreatic cancer and biliary tract cancer groups, there was no patient with serum anti-p53 antibody positive value that exceeded the standard value. In the pancreatic cancer group, the level in 27 patients was below the measurement sensitivity, and for the patients with a level that was highly sensitive, the mean value was $0.716 \mathrm{U} / \mathrm{mL}(0.41-1.23 \mathrm{U} / \mathrm{mL})$. In the biliary tract cancer groups, the level was below the measurement sensitivity in 9 patients, while the mean value for patients with a level that was highly sensitive was $0.716 \mathrm{U} / \mathrm{mL}$ 


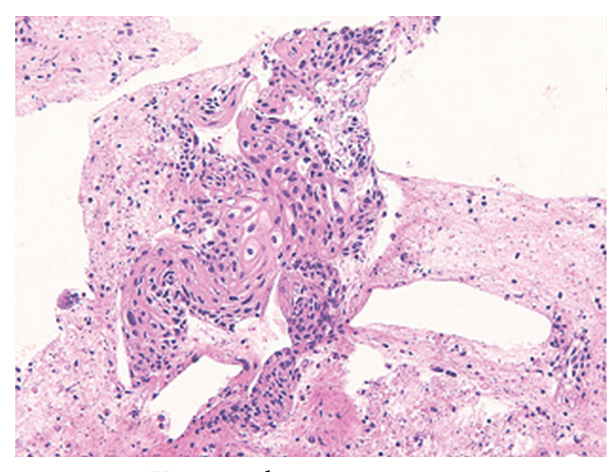

Hematoxylin-eosin staining

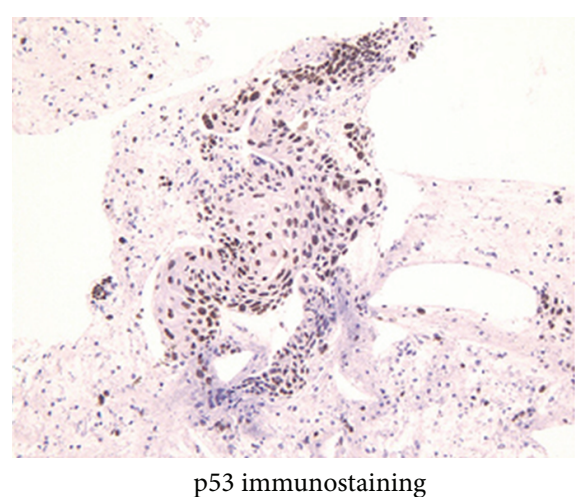

p53 immunostaining

FIGURE 1: EUS-FNA specimen of pancreatic cancer with p53 protein overexpression.

TABle 3: Assay of p53 antibody, CEA, and CA19-9.

\begin{tabular}{lccccc}
\hline & \multicolumn{2}{c}{ Pancreatic cancer } & \multicolumn{2}{c}{ Biliary tract cancer } & \multicolumn{2}{c}{ Pancreatobiliary cancer } \\
& Mean $\pm \mathrm{SD}^{* 1}$ & $\mathrm{CV}^{* 2}$ & Mean $\pm \mathrm{SD}^{* 1}$ & $\mathrm{CV}^{* 2}$ & $\mathrm{Mean}^{* 1} \mathrm{SD}^{* 1}$ \\
\hline p53 antibody $(\mathrm{U} / \mathrm{mL})$ & $0.716 \pm 0.30$ & 0.42 & $0.716 \pm 0.42$ & 0.59 & $0.716 \pm 0.31$ \\
CEA (ng/mL) & $38.33 \pm 146.8$ & 3.83 & $21.42 \pm 25.0$ & 1.16 & $34.01 \pm 127.05$ \\
CA19-9 (U/L) & $3142.9 \pm 9146.8$ & 2.91 & $5859.8 \pm 16446.5$ & 2.79 & $3836.6 \pm 11311.7$ \\
\hline
\end{tabular}

${ }^{* 1} \mathrm{SD}$ : standard deviation.

${ }^{* 2} \mathrm{CV}$ : coefficient of variation.

TABLE 4: Detection of p53 antibody, CEA, and CA19-9.

\begin{tabular}{|c|c|c|c|c|c|c|c|}
\hline & \multicolumn{7}{|c|}{ Pancreatic cancer } \\
\hline & Sensitivity & Specificity & $\mathrm{PPV}^{* 1}$ & $\mathrm{NPV}^{* 2}$ & $\mathrm{FPR}^{* 3}$ & $\mathrm{FNR}^{* 4}$ & Accuracy \\
\hline p53 antibody & $0.0 \%$ & $83.8 \%$ & $0.0 \%$ & $42.6 \%$ & $16.1 \%$ & $100.0 \%$ & $39.3 \%$ \\
\hline CEA & $42.8 \%$ & $93.5 \%$ & $88.2 \%$ & $59.1 \%$ & $6.4 \%$ & $57.1 \%$ & $66.6 \%$ \\
\hline CA19-9 & $85.7 \%$ & $90.3 \%$ & $90.9 \%$ & $84.8 \%$ & $9.6 \%$ & $10.6 \%$ & $87.8 \%$ \\
\hline
\end{tabular}

${ }^{* 1} \mathrm{PPV}$ : positive predictive value.

${ }^{* 2} \mathrm{NPV}$ : negative predictive value.

${ }^{* 3} \mathrm{FPR}$ : false positive rate.

${ }^{* 4}$ FNR: false negative rate.

TABLE 5: Detection of anti-p53 antibody, CEA, and CA19-9.

\begin{tabular}{|c|c|c|c|c|c|c|c|}
\hline & \multicolumn{7}{|c|}{ Biliary tract cancer } \\
\hline & Sensitivity & Specificity & $\mathrm{PPV}^{* 1}$ & $\mathrm{NPV}^{* 2}$ & $\mathrm{FPR}^{* 3}$ & $\mathrm{FNR}^{* 4}$ & Accuracy \\
\hline p53 antibody & $0.0 \%$ & $83.8 \%$ & $0.0 \%$ & $42.6 \%$ & $16.1 \%$ & $100.0 \%$ & $39.3 \%$ \\
\hline CEA & $41.6 \%$ & $93.5 \%$ & $29.4 \%$ & $59.1 \%$ & $6.4 \%$ & $58.3 \%$ & $51.5 \%$ \\
\hline CA19-9 & $91.6 \%$ & $93.5 \%$ & $33.3 \%$ & $84.8 \%$ & $9.6 \%$ & $8.3 \%$ & $59.0 \%$ \\
\hline
\end{tabular}

${ }^{* 1} \mathrm{PPV}$ : positive predictive value.

${ }^{* 2} \mathrm{NPV}$ : negative predictive value.

${ }^{* 3} \mathrm{FPR}$ : false positive rate.

${ }^{* 4}$ FNR: false negative rate.

TABle 6: Detection of anti-p53 antibody, CEA, and CA19-9.

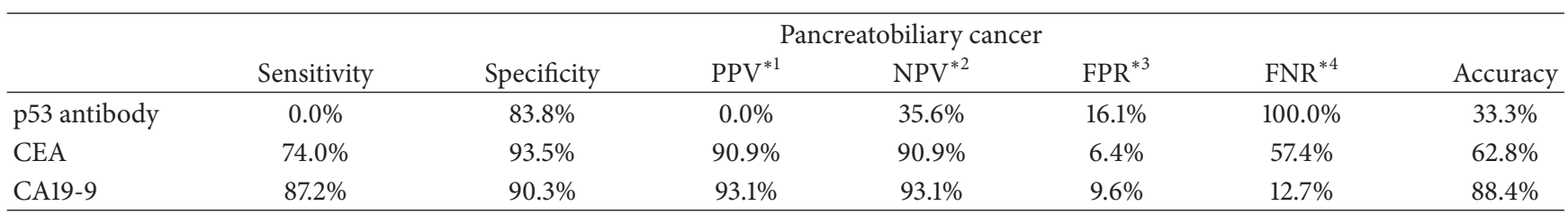

${ }^{* 1} \mathrm{PPV}$ : positive predictive value.

${ }^{* 2} \mathrm{NPV}$ : negative predictive value.

${ }^{* 3}$ FPR: false positive rate.

${ }^{* 4}$ FNR: false negative rate. 
TABLE 7: Positive rate of serum p53 antibody and p53 overexpression.

\begin{tabular}{lccc}
\hline & Pancreatic cancer & Biliary tract cancer & Pancreatobiliary cancer \\
\hline p53 antibody & $0 / 35(0 \%)$ & $0 / 12(0 \%)$ & $0 / 47(0 \%)$ \\
p53 overexpression & $7 / 16(43.7 \%)$ & $5 / 9(55.5 \%)$ & $12 / 25(48.0 \%)$ \\
\hline
\end{tabular}

TABLE 8: Detection of p53 immunohistochemical analysis.

\begin{tabular}{lccccccc}
\hline & Sensitivity & Specificity & PPV $^{* 1}$ & NPV $^{* 2}$ & FPR $^{* 3}$ & FNR $^{* 4}$ & Accuracy \\
\hline Pancreatic cancer & $43.7 \%$ & $100.0 \%$ & $0.0 \%$ & $56.2 \%$ & $100.0 \%$ & $35.7 \%$ & $57.1 \%$ \\
Biliary tract cancer & $55.5 \%$ & $100.0 \%$ & $0.0 \%$ & $44.4 \%$ & $100.0 \%$ & $50.0 \%$ & $69.2 \%$ \\
Pancreatobiliary cancer & $48.0 \%$ & $100.0 \%$ & $0.0 \%$ & $52.0 \%$ & $100.0 \%$ & $40.9 \%$ & $61.7 \%$ \\
\hline
\end{tabular}

${ }^{* 1} \mathrm{PPV}$ : positive predictive value.

${ }^{* 2} \mathrm{NPV}$ : negative predictive value.

${ }^{* 3} \mathrm{FPR}$ : false positive rate.

${ }^{* 4}$ FNR: false negative rate.

(0.41-1.20 U/mL). In the pancreatobiliary cancer group, the mean value for patients with a level that was highly sensitive was $0.716 \mathrm{U} / \mathrm{mL}(0.41-1.23 \mathrm{U} / \mathrm{mL})$ (Tables 3, 4, 5, and 6).

4.3. p53 Immunohistochemistry. Rate of p53 protein overexpression in the 16 patients (surgical resection specimens from 5 patients and biopsy specimens from 11 patients) of the pancreatic cancer group that could be tested was $43.7 \%$ (7 patients) and in the 9 patients (surgical resection specimens from 2 patients and biopsy specimens from 7 patients) of the biliary tract cancer group was $55.5 \%$ (5 patients). In the pancreatobiliary cancer group, the rate was $48.0 \%$ (Tables 7 and 8). Among the patients with benign pancreatobiliary diseases (biopsy specimens from 9 patients), the rate of p53 protein overexpression was $0 \%$.

\section{Discussion}

The p53 gene encodes a 53-kd DNA binding nuclear phosphoprotein with a short half-life that negatively regulates cell growth and proliferation, and its alteration or loss is thought to deprive cells of these inhibitory signals [22-24]. Several investigators have reported that pancreatic ductal cancers frequently show mutations of the p53 gene [25-27] as in biliary tract cancer [28-31]. Thus, there may be an obvious potential for the measurement of p53 gene products, namely, p53 protein, to diagnose pancreatobiliary malignancy.

So far, the main procedures for detecting p53 gene mutation are the analysis of gene sequences from RNA eluted from tissues such as resected materials and the detection of the mutant p53 protein by immunostaining. Induction of serum anti-p53 antibody against mutant $\mathrm{p} 53$ protein in cancer cells has been reported previously $[32,33]$. Development of the ELISA kit that detects anti-p53 antibody is expected to be clinically useful as a screening test because it will enable the easy prediction of gene mutation.

According to the review by Soussi [34] in 2000, there is no report on biliary tract cancer. In terms of pancreatic cancer, previous reports showed various levels of positive rate of serum p53 antibodies, ranging from $4 \%$ to $27 \%$ [34]. In addition, Shimada et al. [16] investigated 1085 solid tumor patients with a total of 15 types of solid tumors in 2003 and reported a positive rate of $16 \%$ for biliary tract cancer and $10 \%$ for pancreatic cancer. With regard to the ratio of p53 mutations in pancreatobiliary cancers, several investigators have reported that they emerged in approximately 40\% [25-31]. On the other hand, to date, there are many articles on the usefulness of p53 immunostaining for the diagnosis of pancreatic cancers [35-39] and biliary tract cancers [33-37]. The ratio of protein overexpression of pancreatobiliary cancers is approximately $60 \%$ though the range is from $40 \%$ to $80 \%$ [35-44]. There is discrepancy of positive rate between p 53 mutation and protein expression. One of reason for this may be caused by the criteria for p53 overexpression. Current commercially available antibodies for P53 stains are both the wild-type and mutant p53 proteins. Nevertheless, p53 overexpression is thought to reflect p53 mutation. In fact, two reports have revealed that 553 protein overexpression correlates well with gene mutation in gallbladder cancer [45] and cholangiocarcinoma [46]. In the present study, we strictly defined that more than $70 \%$ of positive cells indicates overexpression, suggesting p53 mutation. As a result, the p53 overexpression positive rate was $43.7 \%$ in pancreatic cancer and $55.5 \%$ in biliary tract cancer. Surprisingly, in the present study, no anti-p53 antibody was detected in both pancreatic cancer and biliary tract cancer though the levels of CA19-9 or CEA were elevated in the same cases. We guessed that the reasons why p53 overexpression could not induce serum antibody were that p53 overexpression does not necessarily induce serum antibody and possibly some immunological malformation might be present in the patients with pancreatobiliary cancers.

Considering the clinical application of the current serum p53-antibody measurement and p53 immunostaining to diagnose pancreatobiliary malignancy, p53 immunostaining appears to be useful compared to serum anti-p53 antibody because of higher positive rate. In the present study, although p53 immunostaining was also used only for surgically resected specimens, the application of p53 immunostaining using biopsy specimens may be useful to distinguish benign from malignant as we previously described [44]. 
Therefore, we should compare serum anti-p53 antibody with p53 immunostaining using biopsy specimens as a next step in the near future.

There are some limitations in this study because of the small sample size, lack of a control group, and no analysis of p53 gene mutation.

In conclusion, our study clarified that serum anti-P53 antibody measurement does not contribute to the diagnosis of pancreatobiliary cancers. Instead, traditional p53 immunostaining still appears to be valuable in combination with standard procedures.

\section{References}

[1] K. E. Bakkevold, B. Arnesjo, and B. Kambestad, "Carcinoma of the pancreas and papilla of Vater: presenting symptoms, signs, and diagnosis related to stage and tumour site. A prospective multicentre trial in 472 patients," Scandinavian Journal of Gastroenterology, vol. 27, no. 4, pp. 317-325, 1992.

[2] A. DelMaschio, A. Vanzulli, S. Sironi et al., "Pancreatic cancer versus chronic pancreatitis: diagnosis with CA 19-9 assessment, US, CT, and CT-guided fine-needle biopsy," Radiology, vol. 178, no. 1, pp. 95-99, 1991.

[3] S. Bipat, S. S. Phoa, O. M. van Delden et al., "Ultrasonography, computed tomography and magnetic resonance imaging for diagnosis and determining resectability of pancreatic adenocarcinoma: a meta-analysis," Journal of Computer Assisted Tomography, vol. 29, no. 4, pp. 438-445, 2005.

[4] E. Lopez Hanninen, H. Amthauer, N. Hosten et al., "Prospective evaluation of pancreatic tumors: accuracy of MR imaging with MR cholangiopancreatography and MR angiography," Radio$\log y$, vol. 224, no. 1, pp. 34-41, 2002.

[5] K. Satake, Y. S. Chung, H. Yokomatsu et al., "A clinical evaluation of various tumor markers for the diagnosis of pancreatic cancer," International Journal of Pancreatology, vol. 7, no. 1-3, pp. 25-36, 1990.

[6] O. Nazli, A. D. Bozdag, T. Tansug, R. Kir, and E. Kaymak, "The diagnostic importance of CEA and CA 19-9 for the early diagnosis of pancreatic carcinoma," Hepato-Gastroenterology, vol. 47, no. 36, pp. 1750-1752, 2000.

[7] A. H. Patel, D. M. Harnois, G. G. Klee, N. F. Larusso, and G. J. Gores, "The utility of CA 19-9 in the diagnoses of cholangiocarcinoma in patients without primary sclerosing cholangitis," American Journal of Gastroenterology, vol. 95, no. 1, pp. 204-207, 2000.

[8] J. M. Nigro, S. J. Baker, A. C. Preisinger et al., "Mutations in the p53 gene occur in diverse human tumour types," Nature, vol. 342, no. 6250, pp. 705-708, 1989.

[9] T. Itoi, A. Sofuni, T. Kurihara et al., PancreaticobiliaryTract Disease and Genetic Diagnosis: Common Points between Endoscopy and Molecular Pathology Diagnosis, Shinko Igaku Publishers, Tokyo, Japan, 2005.

[10] T. Fujimori, C. Sakamoto, Y. Hoshihara, and Y. Kato, DiagnosisTreatment of Gastroenterological Cancer: Common Points between Endoscopy and Pathology, Shinko Igaku Publishers, Tokyo, Japan, 2005.

[11] T. Itoi, K. Nakamura, A. Sofuni et al., "Pathology diagnosis and molecular diagnosis in biliary tract disease," Manual of Gastroenterology, vol. 18, pp. 1161-1169, 2003.

[12] K. Ohasha and Y. Nakajima, "Characteristics of genetic abnormalities seen from the site of onset and progress pattern of biliary tract cancer," Journal of Biliary Tract and Pancreas, vol. 25, pp. 357-364, 2004.

[13] H. Katakura and F. Itoh, "Molecular diagnosis," Japanese Journal of Clinical Medicine, vol. 64, pp. 422-425, 2006.

[14] C. M. Barton, S. L. Staddon, C. M. Hughes et al., "Abnormalities of the p53 tumour suppressor gene in human pancreatic cancer," British Journal of Cancer, vol. 64, no. 6, pp. 1076-1082, 1991.

[15] M. S. Redston, C. Caldas, A. B. Seymour et al., "p53 mutations in pancreatic carcinoma and evidence of common involvement of homocopolymer tracts in DNA microdeletions," Cancer Research, vol. 54, no. 11, pp. 3025-3033, 1994.

[16] H. Shimada, T. Ochiai, and F. Nomura, "Titration of serum p53 antibodies in 1085 patients with various types of malignant tumors a multiinstitutional analysis by the Japan p53 Antibody Research Group," Cancer, vol. 97, no. 3, pp. 682-689, 2003.

[17] H. Shimada, K. Nakajima, T. Ochiai et al., "Detection of serum p53 antibodies in patients with esophageal squamous cell carcinoma: correlation with clinicopathologic features and tumor markers," Oncology Reports, vol. 5, no. 4, pp. 871-874, 1998.

[18] K. Nakajima, T. Suzuki, H. Shimada, H. Hayashi, A. Takeda, and T. Ochiai, "Detection of preoperative serum anti-p53 antibodies in gastric cancer," Tumor Biology, vol. 20, no. 3, pp. 147-152, 1999.

[19] A. Takeda, K. Nakajima, H. Shimada et al., "Clinical significance of serum p53 antibodies detection on chemosensitivity assay in human colorectal cancer," Journal of Surgical Oncology, vol. 71, pp. 112-116, 1999.

[20] H. Shimada, A. Takeda, M. Arima et al., "Serum p53 antibody is a useful tumor marker in superficial esophageal squamous cell carcinoma," Cancer, vol. 89, pp. 1677-1683, 2000.

[21] A. Takeda, H. Iseki, H. Shimada et al., "Clinical significance of measurements of serum p53-antibody as a predictive marker of relapse in curative resection of colon cancer cases," Japanese Journal of Cancer Clinics, vol. 54, pp. 689-694, 2008.

[22] A. J. Levine, J. Momand, and C. A. Finlay, "The p53 tumour suppressor gene," Nature, vol. 351, no. 6326, pp. 453-456, 1991.

[23] D. P. Lane, "p53, guardian of the genome," Nature, vol. 358, no. 6381, pp. 15-16, 1992.

[24] G. Farmer, J. Bargonetti, H. Zhu, P. Friedman, R. Prywes, and C. Prives, "Wild-type p53 activates transcription in vitro," Nature, vol. 358, no. 6381, pp. 83-86, 1992.

[25] C. M. Barton, S. L. Staddon, C. M. Hughes et al., "Abnormalities of the p53 tumour suppressor gene in human pancreatic cancer," British Journal of Cancer, vol. 64, no. 6, pp. 1076-1082, 1991.

[26] A. Scarpa, P. Capelli, K. Mukai et al., "Pancreatic adenocarcinomas frequently show p53 gene mutations," American Journal of Pathology, vol. 142, no. 5, pp. 1534-1543, 1993.

[27] G. Casey, Y. Yamanaka, H. Friess et al., "p53 Mutations are common in pancreatic cancer and are absent in chronic pancreatitis," Cancer Letters, vol. 69, no. 3, pp. 151-160, 1993.

[28] N. Yokoyama, J. Hitomi, H. Watanabe et al., "Mutations of p53 in gallbladder carcinomas in high-incidence areas of Japan and Chile," Cancer Epidemiology Biomarkers and Prevention, vol. 7, no. 4, pp. 297-301, 1998.

[29] J. Wang, X. Wang, S. Xie et al., "P53 status and its prognostic role in extrahepatic bile duct cancer: a meta-analysis of published studies," Digestive Diseases and Sciences, vol. 56, no. 3, pp. 655662, 2011.

[30] C. D. Briggs, C. P. Neal, C. D. Mann, W. P. Steward, M. M. Manson, and D. P. Berry, "Prognostic molecular markers in cholangiocarcinoma: a systematic review," European Journal of Cancer, vol. 45, no. 1, pp. 33-47, 2009. 
[31] S. A. Khan, S. D. Taylor-Robinson, P. L. Carmichael, N. Habib, N. R. Lemoine, and H. C. Thomas, "Analysis of p53 mutations for a mutational signature in human intrahepatic cholangiocarcinoma," International Journal of Oncology, vol. 28, no. 5, pp. 1269-1277, 2006.

[32] L. V. Crawford, D. C. Pim, and R. D. Bulbrook, "Detection of antibodies against the cellular protein p53 in sera from patients with breast cancer," International Journal of Cancer, vol. 30, no. 4, pp. 403-408, 1982.

[33] R. Lubin, B. Schlichtholz, J. L. Teillaud et al., "p53 antibodies in patients with various types of cancer: assay, identification, and characterization," Clinical Cancer Research, vol. 1, no. 12, pp. 1463-1469, 1995.

[34] T. Soussi, "The p53 tumor suppressor gene: from molecular biology to clinical investigation," Annals of the New York Academy of Sciences, vol. 910, pp. 121-139, 2000.

[35] C. R. Boschman, S. Stryker, J. K. Reddy, and M. S. Rao, "Expression of p53 protein in precursor lesions and adenocarcinoma of human pancreas," American Journal of Pathology, vol. 145, no. 6, pp. 1291-1295, 1994.

[36] J. A. DiGiuseppe, R. H. Hruban, S. N. Goodman et al., "Overexpression of p53 protein in adenocarcinoma of the pancreas," American Journal of Clinical Pathology, vol. 101, no. 6, pp. 684688, 1994.

[37] K. Kasuya, H. Watanabe, T. Nakasako, Y. Ajioka, and Y. Koyanagi, "p53 protein overexpression and K-ras codon 12 mutation in pancreatic ductal carcinoma: correlation with histologic factors," Pathology International, vol. 47, no. 8, pp. 531-539, 1997.

[38] S. K. Apple, J. R. Hecht, D. N. Lewin, S. A. Jahromi, W. W. Grody, and R. K. Nieberg, "Immunohistochemical evaluation of K-ras, p53, and HER-2/neu expression in hyperplastic, dysplastic, and carcinomatous lesions of the pancreas: evidence for multistep carcinogenesis," Human Pathology, vol. 30, no. 2, pp. 123-129, 1999.

[39] A. V. Biankin, J. G. Kench, A. L. Morey et al., "Overexpression of p21WAF1/CIP1 is an early event in the development of pancreatic intraepithelial neoplasia," Cancer Research, vol. 61, no. 24, pp. 8830-8837, 2001.

[40] M. Moreno, F. Pimentel, A. F. Gazdar, I. I. Wistuba, and J. F. Miquel, "TP53 abnormalities are frequent and early events in the sequential pathogenesis of gallbladder carcinoma," Annals of Hepatology, vol. 4, no. 3, pp. 192-199, 2005.

[41] A. Wee, M. Teh, and G. C. Raju, "Clinical importance of p53 protein in gall bladder carcinoma and its precursor lesions," Journal of Clinical Pathology, vol. 47, no. 5, pp. 453-456, 1994.

[42] S. A. Ahrendt, A. Rashid, J. T. Chow, C. F. Eisenberger, H. A. Pitt, and D. Sidransky, "p53 overexpression and K-ras gene mutations in primary sclerosing cholangitis-associated biliary tract cancer," Journal of Hepato-Biliary-Pancreatic Surgery, vol. 7, no. 4, pp. 426-431, 2000.

[43] S. Horie, K. Endo, H. Kawasaki, and T. Terada, "Overexpression of MDM2 protein in intrahepatic cholangiocarcinoma: relationship with p53 overexpression, Ki-67 labeling, and clinicopathological features," Virchows Archiv, vol. 437, no. 1, pp. 25-30, 2000.

[44] T. Itoi, Y. Shinohara, K. Takeda et al., "Detection of telomerase activity in biopsy specimens for diagnosis of biliary tract cancers," Gastrointestinal Endoscopy, vol. 52, no. 3, pp. 380-386, 2000.

[45] T. Itoi, H. Watanabe, M. Yoshida, Y. Ajioka, K. Nishikura, and T. Saito, "Correlation of p53 protein expression with gene mutation in gall-bladder carcinomas," Pathology International, vol. 47, no. 8, pp. 525-530, 1997.

[46] X.-F. Liu, H. Zhang, S.-G. Zhu et al., "Correlation of p53 gene mutation and expression of P53 protein in cholangiocarcinoma," World Journal of Gastroenterology, vol. 12, no. 29, pp. 4706-4709, 2006. 


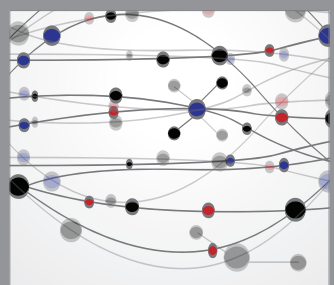

The Scientific World Journal
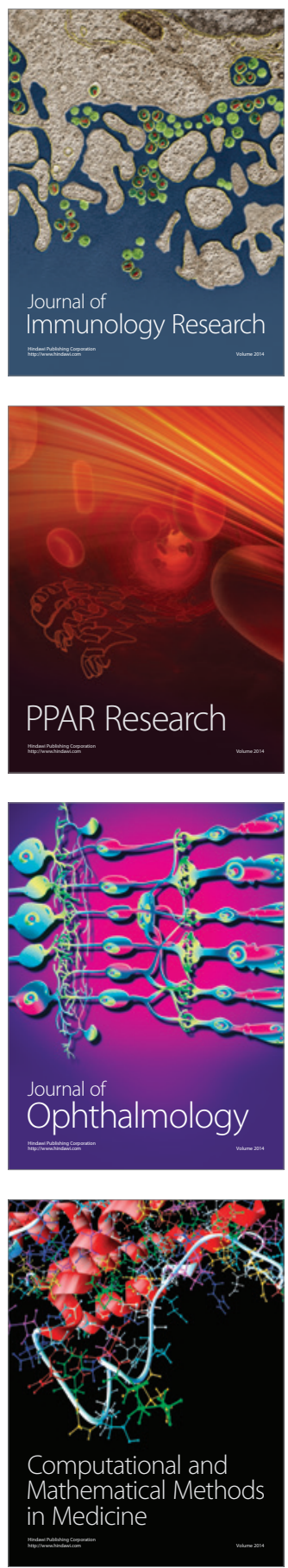

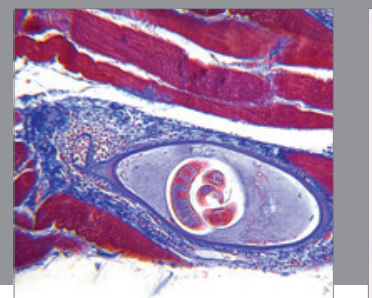

Gastroenterology

Research and Practice
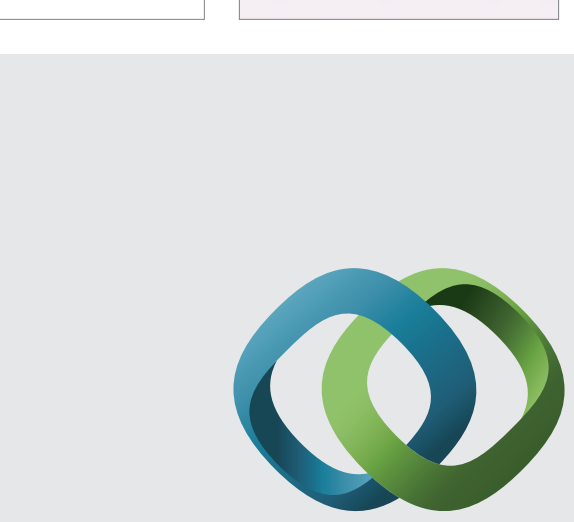

\section{Hindawi}

Submit your manuscripts at

http://www.hindawi.com
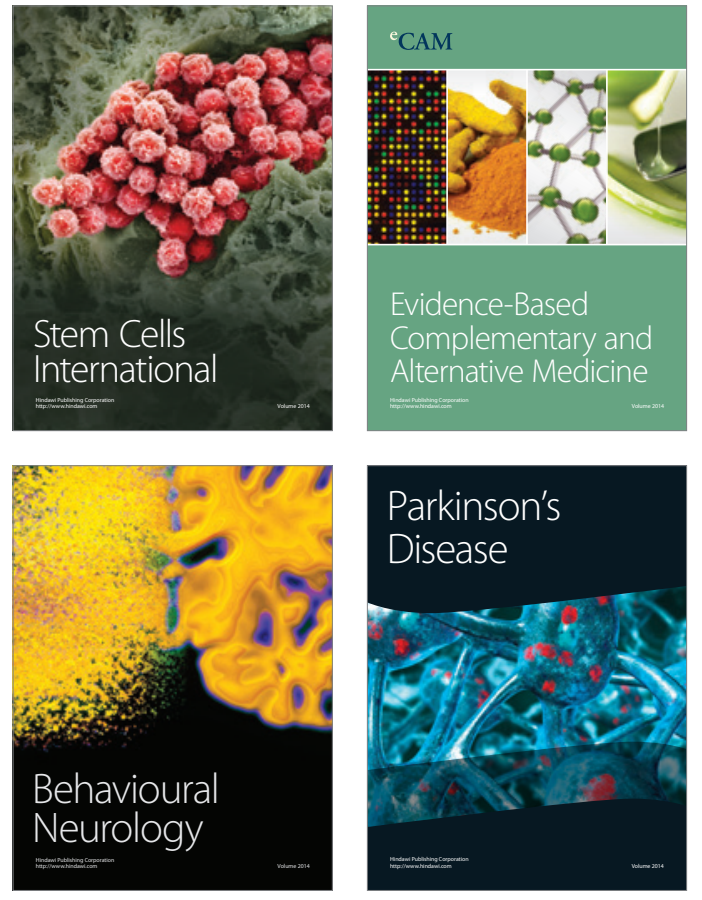
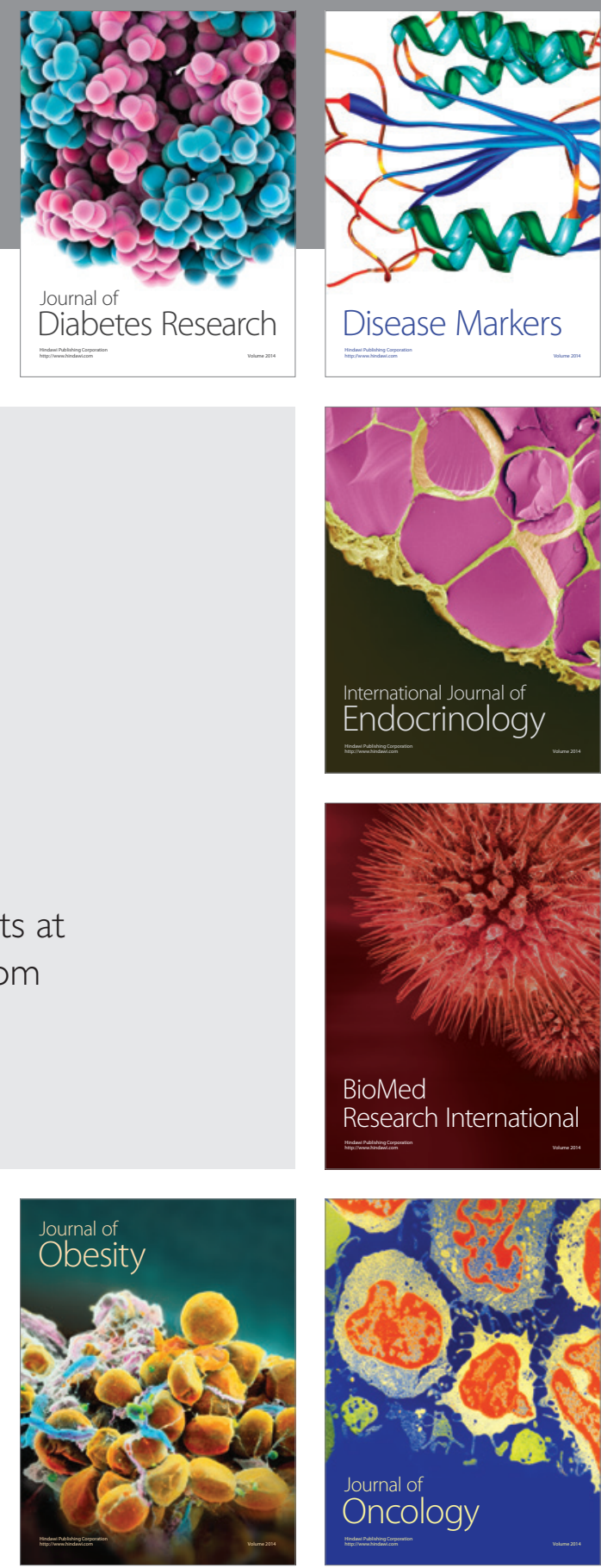

Disease Markers
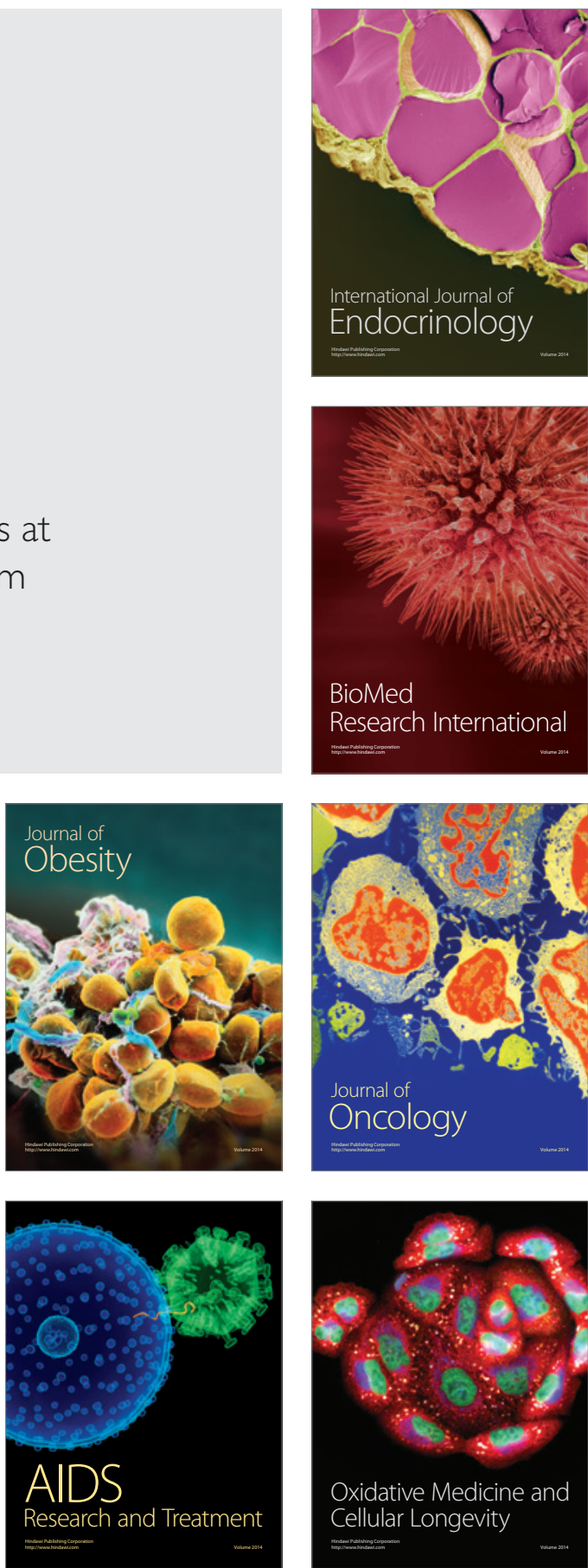